\title{
Drying kinetics and quality characteristics of beetroot slices under hot air followed by microwave finish drying
}

\author{
Kulwinder Kaur* and A. K. Singh \\ Department of Processing and Food Engineering, Punjab Agricultural University, Ludhiana, 141004 India. \\ Received 3 August, 2013: Accepted 21 March, 2014
}

\begin{abstract}
The experiments were conducted to evaluate the impact of air temperature and microwave power level on drying behavior and quality of beetroot. The osmotically pretreated samples in sugar-salt mixed solution were further dehydrated using convective tray drier upto a moisture content of 40 to $60 \% \mathrm{db}$ (the point where drying rate became slow) followed by microwave drying to a moisture content of $6 \%$ (bone dry conditions) to overcome the slow removal of moisture content in the end. Three levels of air temperature 55, 65 and $75^{\circ} \mathrm{C}$ and microwave power 540,810 and $1080 \mathrm{~W}$ each were selected and readings on moisture content, rehydration ratio, color, total soluble solid, water activity and hardness were taken. The results showed that osmotic pretreatment prior to hot air microwave finish drying improved the final quality of dehydrated sample. The drying took place in the falling rate drying period regardless of the drying conditions. Drying at high air temperature $\left(75^{\circ} \mathrm{C}\right)$ followed by high microwave power $(1080 \mathrm{~W})$ witnessed increased drying rates and substantial shortening of the drying time. Two term and logarithmic model successfully described the drying kinetics of convectively dehydrated and microwave finish dehydrated beetroot slices respectively. Rehydration characteristics of beetroot were improved for samples dehydrated at $55^{\circ} \mathrm{C}$ and $1080 \mathrm{~W}$, which helped in reduction of shrinkage and case hardening. A greater change in color resulted due to decreased $L$ and $b$ values and increased ' $a$ ' value with increase in both air temperature and microwave power. Sample dehydrated at high air temperature followed by high microwave power exhibited high water activity, high total soluble solids (TSS) and improved hardness as compared to fresh sample.
\end{abstract}

Key words: Beetroot, air drying, microwave finish drying, quality.

\section{INTRODUCTION}

In recent years, with the increase of the human being's awareness for health and knowledge about healthy function of natural products, beetroot produces have gradually attracted extensive attention worldwide. Beetroot (Beta vulgaris L.) is rich in valuable, active compounds such as carotenoids, glycine betaine,

${ }^{*}$ Corresponding author. E-mail: kulwinder.verma @gma il.com

Author(s) a gree that this a rtic le rema in pemanently open access under the terms of the Creative Commons Attribution License 4.0 Intemational Lic ense 
saponins, betacyanines, folates, betanin, polyphenols and flavonoids (Figiel, 2010) and popularly consumed as red food colorants, e.g. to improve the colour of tomato paste, sauces, desserts, jams and jellies, ice cream, sweets and cereals. Also, it has potentials for cancer prevention and suppression due to its high content of antioxidants.

However, fresh beetroot contains high moisture content and is very susceptible to deterioration due to lack of adequate preservation techniques. There is need to develop efficient preservation method which can ensure the microbial safety of biological products. The combination of osmo- convective dehydration with a mild drying process such as microwave drying is considered to be worth because of its high potential to improve the overall quality of dehydrated fruit products in a shorter time than other drying methods (Prothon et al., 2001).

Osmotic dehydration is described as the partial dehydration of fruits through the process of osmosis, which involves immersion of fruit in hypertonic solution at given temperature and for specific period of time (Ponting, 1973). The osmotic dehydration is commonly used as a pre-step before drying because it improves nutritional, sensorial and functional aspects of foods, without changing its colour, texture and aroma. After this initial step, it has to be followed by other drying methods such as freezing, vacuum drying, air drying, microwave drying and combination of any of these drying methods, to produce shelf stable product.

Use of microwave drying is an important technique in industrial drying and food processing because it has several advantages over convective heating. For instance, shorter drying time, improved product quality, and flexibility in producing a wide variety of dehydrated products. And also because of the concentrated energy of microwave system, only 20 to $40 \%$ of the floor space is required, as compared to conventional heating and drying equipments. Although microwave heating can readily deliver energy to generate heat in the moist portion within foods, one of its major drawbacks is the inherent uneven heating, possible textural damage, and limited product penetration of the microwave radiation into the product. To overcome the limitations of microwave drying, it can be combined with great variety of other methods (Zhang et al., 2006). Moreover, microwave drying, like conventional drying, is caused by water vapour pressure differences between interior and surface regions which provide a driving force for rapid removal of moisture diffusion and prevent the shrinkage of tissue structure. In some cases applying microwave drying in the falling rate period during drying can also be proven efficient in removing bound water from the product. Keeping in view the above aspects, it has been suggested that microwave energy should be applied in the falling rate period or at low moisture content for finish drying (Prabhanjan et al., 1995).

In recent years, microwave drying has gained great interest in industrial applications due to increased demand for plant-origin foods in fast-dehydrated form. Several work has been reported on microwave drying of raisins (Kostaropoulos and Saravacos, 1995), apple and mushroom (Funebo and Ohlsson, 1998), banana (Maskan, 2000), potato and carrot (Jia et al., 2003), orange slices (Ruiz Diaz et al., 2003), cylindercal apples (Andres et al., 2004), carrots and garlic (Cui et al., 2005) and grapes (Clary et al., 2005).

However, there is limited coverage related to hot airmicrowave finish drying of osmotically pretreated beetroot slices. Therefore, the aim of this work was to determine the effect of microwave power level and air temperature on the drying kinetics and some quality parameters of beetroot slices in terms of rehydration ratio, color, total soluble solid and water activity and hardness.

\section{MATERIALS AND METHODS}

\section{Raw material and sample preparation}

Beetroot (B. vulgaris L.) were purchased from a local market located at Ludhiana (India) and stored at $5^{\circ} \mathrm{C}$ prior to experiments. Because of high maturity level of beetroot, it was always ensured that firm beetroot were chosen for the dehydration experiments. The beetroots were dehydrated as per process flow diagram as shown in Figure 1. The beetroot were first washed, peeled and then were cut into $10 \times 10 \times 3 \mathrm{~mm}$ slices using sharp steel knife. A solution of sugar $\left(72.76^{\circ}\right.$ Brix) and salt $(5 \%)$ was prepared by dissolving adequate proportion in measured amount of water. Salt was used as it retards oxidative non-enzymatic browning (Kumar et al., 2009).

\section{Drying experiments}

The osmotic dehydration experiment was carried out with a salt sugar mixed solution over a period of $3 \mathrm{~h}$ at $50.59^{\circ} \mathrm{C}$. Water loss, solid gain and weight reduction ( $\mathrm{g} / 100 \mathrm{~g}$ of initial mass) were calculated in order to determine the efficiency of osmotic pretreatment. The osmotically pretreated samples were placed in thin layer on perforated sieves for further drying at different air temperatures ranging from 55 to $75^{\circ} \mathrm{C}$ until the moisture content dropped to 40 to $60 \%, \mathrm{db}$ of initial moisture content. Each convectively pre dried (CPD) portion was then divided into three equal portions. The divided portions were dried by microwave dryer at three different levels of microwave power ranging from 540 to $1080 \mathrm{~W}$. Three replications were taken for each experiment to get an average values. The drying kinetics was studied by taking out the samples from dryers at regular intervals of 30 and $1 \mathrm{~min}$ for convective drying and microwave drying, respectively and measuring moisture content calculated using standard method (AOAC, 2000).

Drying rate was determined by moisture content $(\%, \mathrm{db})$ decrease of the sample per unit time $(\min )$ as given by Ceylan et al. (2007):

Drying rate, $\frac{d M}{d T}=\frac{\text { Moisture ramoval (Ga,db) }}{\text { time teken for moistare removal (min) }}$

\section{Modeling of drying curves}

During drying, there is a severe reduction in dimension of sample. Therefore, only two diffusion models named logarithmic and two 


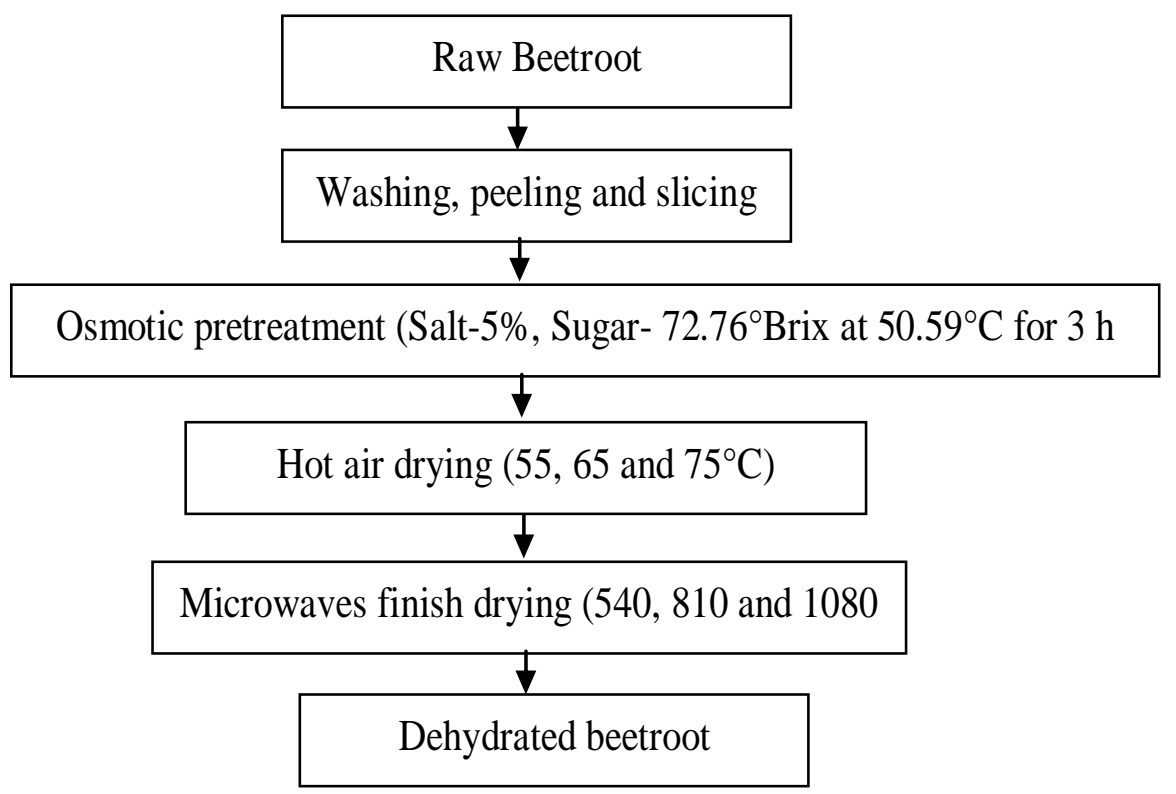

Figure 1. Flow diagram of process used to dry beetroot.

terms were used to evaluate drying kinetics over Fick's diffusion model using following expressions.

Logarithmic model, $M R=a \exp (-k t)+b$

Two term model, $M R=a \exp \left(-k_{0} t\right)+b \exp \left(k_{1} t\right)$

Regression analysis was conducted to fit the mathematical models by the statistical package for social sciences (SPSS version 16.0). The value of $R^{2}$, RMSE and $P \%$ was calculated using following expressions:

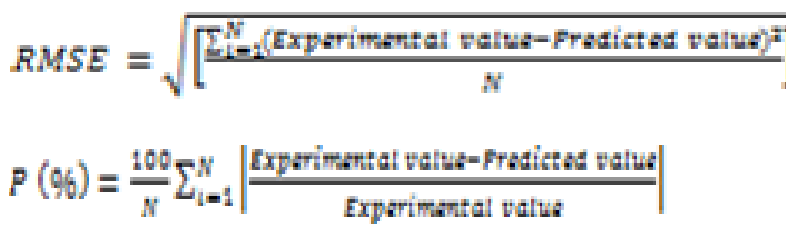

The best model describing the drying characteristics of samples was chosen as the one with the highest coefficient of determination and the least root mean square error (RMSE) and mean relative percent error (P\%) (Madamba, 2003; Sacilik et al., 2006).

\section{Quality evaluation}

For quality evaluation, similar drying experiments were conducted under same drying conditions. Drying was terminated when moisture content reached $6 \%$ or below on dry basis. The samples were then allowed to come to room temperature, packed and stored for quality analysis. The dried sample was analyzed for its quality by estimating the rehydration capacity, colour, water activity, total soluble solid and hardness.

\section{Rehydration ratio}

Rehydration test was performed by soaking known weight (5 to 10 g) of each sample in sufficient volume of water in a glass beaker (approximately 30 times the weight of sample) at $95^{\circ} \mathrm{C}$ for $20 \mathrm{~min}$. After soaking, the excess water was removed with the help of filter paper and samples were weighed. In order to minimize the leaching losses, water bath was used for maintaining the defined temperature (Ranganna, 2000). Rehydration ratio (RR) was computed as follows:

Rehydration ratio $(R R)=\frac{\text { Drained weight of rehydrated sample }(\mathrm{g})}{\text { Weight of dehydrated sample used for rehydration }(\mathrm{g})}$

\section{Color}

Color of fresh and dried material was determined using Konica Minlota Colorimeter. The color values were expressed as $\mathrm{L}$ (whiteness/darkness), a (redness/greenness) and b (yellowness/blueness). And also, the color change from fresh beetroot $\Delta \mathrm{E}$, as defined the following, was used to describe the color change during drying:

Color change $\Delta \mathrm{E}=\sqrt{\left(L_{0}-L\right)^{2}+\left(a_{0}-a\right)^{2}+\left(b_{0}-b\right)^{2}}$

Where subscript "0" referred to the colour reading of fresh beetroot, $\mathrm{L}, \mathrm{a}$ and $\mathrm{b}$ indicated brightness, redness and yellowness of dried samples respectively. Fresh beetroot was used as the reference and a larger denoted greater colour change from reference material.

\section{Total soluble solids}

The total soluble solids (TSS) of prepared syrup was found out by using digital refractometer ranging from $\left(0-96^{\circ} \mathrm{Brix}\right)$, which gave the reading directly in Brix. Similarly the total soluble solids of fresh as well as dehydrated sample were also determined by crushing samples and dissolving $2 \mathrm{~g}$ of crushed sample in $20 \mathrm{ml}$ water. The TSS was measured by putting two or three drops of thoroughly dissolved solution on the fixed prism of the digital refractometer and 
press read button. The value of refractive index will appear on display (Ranganna, 2000).

\section{Water activity $\left(a_{w}\right)$}

Water activity of the dried and fresh samples was measured directly in the Hygro Lab make water activity meter. For measurements, one piece of dried beetroot from each sample were taken and placed in a standard measuring cup provided with the water activity meter, and sealed against a sensor block. Reading was displayed on the screen after few minutes.

\section{Hardness}

Hardness of the dried samples was determined with the help of Texture Analyzer TA-Hdi. The samples were compressed by spherical probe. The pre-test speed and post test speed was set at 1.5 and $10 \mathrm{~mm} / \mathrm{s}$ respectively whereas test speed was set at 2 $\mathrm{mm} / \mathrm{s}$ during compression. The height of the peak during compression cycle was defined as hardness $(g-f)$.

\section{RESULTS AND DISCUSSION}

While deciding the quality of dried sample, it is mandatory to compare drying behavior as well as quality attributes. A sample with maximum rehydration, total soluble solid, crispy texture, minimum water activity and an attractive colour is considered as good quality food for marketing. In present study, the effect of complementary drying techniques of hybrid method on drying kinetics and quality indices were evaluated.

\section{Osmotic pretreatment}

The calculated values of water loss (30.36 \pm 0.631$)$, solid gain (5.44 \pm 0.862$)$, weight reduction $(24.92 \pm 0.886)$ and dehydration efficiency $(5.48 \pm 0.529)$ indicated the efficient removal of water with minimum solute uptake by sample dehydrated at optimized osmotic conditions. Also, moisture content of sample with osmotic pretreatment was found to reduce from 80 to $65 \%$ approximately (w/w).

\section{Drying kinetics of beetroot}

The drying curves representing changing trend of moisture profile with respect to drying time showed that the moisture removal was relatively rapid in the initial phase of drying, whereas the successive dynamics of moisture removal decreased and drying began to be time consuming (Figure 2a). However, with microwave drying, initial acceleration of moisture reduction was observed due to an opening of physical structure allowing rapid evaporation and transport of water. The moisture removal was also influence by drying temperature. The results revealed that as the air temperature increased, other drying conditions being same, moisture removal increased thus resulted into substantial decrease in drying time. The drying time at 55,65 and $75^{\circ} \mathrm{C}$ drying air temperature were 270, 180 and $150 \mathrm{~min}$ for beetroot slices of $3 \mathrm{~mm}$ thickness. As it was obvious that the drying time was highest at $55^{\circ} \mathrm{C}$ as compared to 65 and $75^{\circ} \mathrm{C}$ and there was about 33.33 and $44.44 \%$ reduction in drying time for varying temperature from 55 to 65 and $75^{\circ} \mathrm{C}$ respectively. On the other hand with microwave finish drying at $1080 \mathrm{~W}$, the time taken to reduce moisture content (wet basis) from the $36.15 \%$ to a final $4.44 \%$ (56.62 to $4.65 \%$ dry basis) was observed as 6 to 7 min for all treated samples of beetroot. The respective drying times of dried beetroot with 540 and $810 \mathrm{~W}$ were observed as 10 and $8 \mathrm{~min}$ respectively. The total time taken to reduce moisture content up to desire level was also calculated as sum of time taken to convective drying and microwave drying for all treated combinations. On comparison, it was found that savings in drying time of $44.28 \%$ in sample of beetroot could be made in microwave drying with $1080 \mathrm{~W}$ at temperature of $75^{\circ} \mathrm{C}$. The shorter drying time under microwave drying conditions might be due to the additional energy input, rapid heat penetration by microwave and forced expulsion of gases.

Drying rates were calculated as quantity of moisture removed per unit drying time per unit dry solids and presented in Figure 2b. From an examination of figures, it was observed that the drying rate decreased with increase in drying time with some minor exceptions of irrespective of drying temperature. The decrease in drying rate being more drastic and pronounce in initial minutes of drying as compared to the later part of drying. Further it was observed that the drying occurred mostly in the falling rate period (with more than two periods), regardless of drying conditions. Although the beetroot has high moisture content, an expected constant rate period was not observed in the present study owing to smaller thickness of sample allowing rapid drying rate. The observed rate of drying was also controlled by drying temperature. The noticeable falling rate of more than one were probably due to case hardening; a hard layer of migrating soluble solids at the surface of drying surface that created a barrier to moisture migration with passage of drying at high temperature. This phenomenon resulted in to complex changes in physical and chemical structure. Further increase in temperature led to splitting, rupturing and cracking of tissues and forming open structures in the sample, so that moisture transfer occurred with a greater rate from the cracks and an open structure formed. The initial drying rates were as high as $1.69 \mathrm{~g}$ of water $/ \mathrm{g}$ of dry matter at $75^{\circ} \mathrm{C}$ and as low as $0.13 \mathrm{~g}$ of water/g of dry matter during air drying experiment whereas for microwave finish drying large increase in drying rates of about 20 to $80 \%$ at the start of the drying process was resulted with power of 1080 as compared to that with 540 and $810 \mathrm{~W}$ at $75^{\circ} \mathrm{C}$ air temperature. Hence resulted increase in drying rates by microwave drying in 


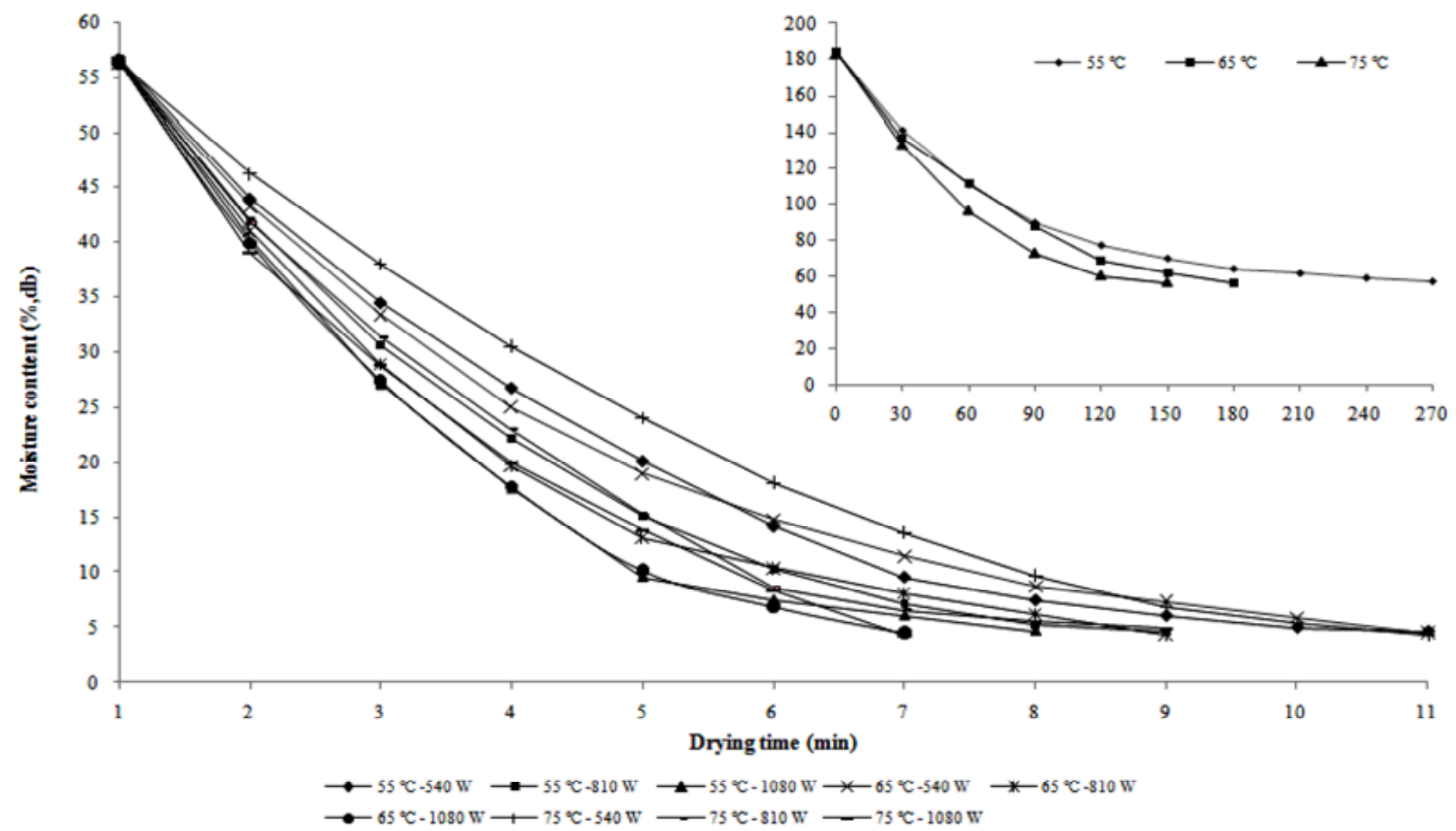

(a)

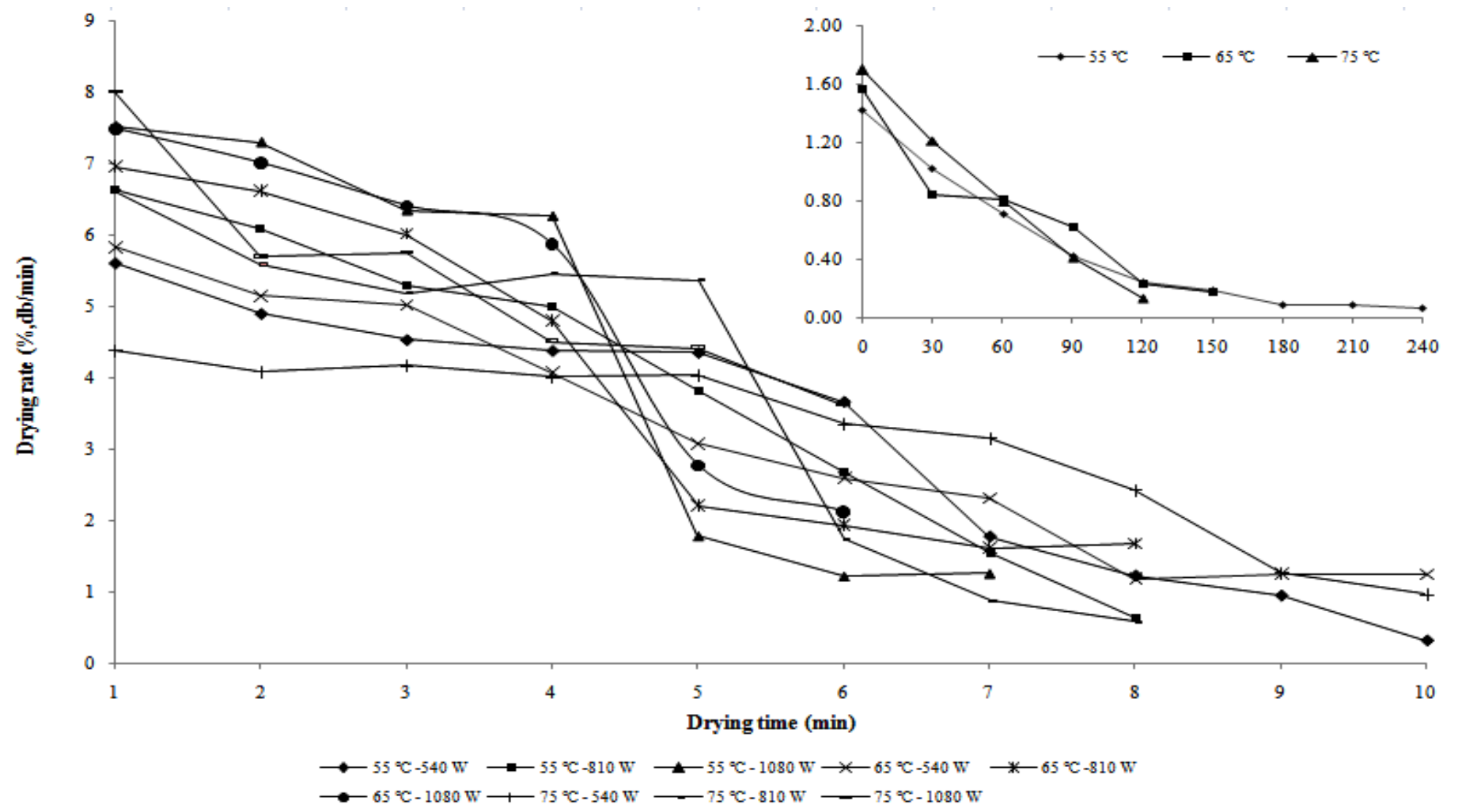

(b)

Figure 2. Variation of (a) Moisture content $(\%, d b)$ vs drying time (min) and (b) drying rate (\%,db/ min) vs drying time (min) during hot airmicrowave finish drying of osmotically pretreated beetroot slices. 
Table 1. Model's parameters and good of fit for drying kinetics during convective followed by microwave drying of osmotically pretreated beetroot slices.

\begin{tabular}{|c|c|c|c|c|c|c|c|c|c|c|c|c|c|}
\hline \multirow{3}{*}{ Models } & \multirow{3}{*}{ Parameter } & \multicolumn{3}{|c|}{ Hot air drying $\left({ }^{\circ} \mathrm{C}\right)$} & \multicolumn{9}{|c|}{ Microwave finish drying (W) } \\
\hline & & \multirow{2}{*}{55} & \multirow{2}{*}{65} & \multirow{2}{*}{75} & \multicolumn{3}{|c|}{$55^{\circ} \mathrm{C}$} & \multicolumn{3}{|c|}{$65^{\circ} \mathrm{C}$} & \multicolumn{3}{|c|}{$75^{\circ} \mathrm{C}$} \\
\hline & & & & & 540 & 810 & 1080 & 540 & 810 & 1080 & 540 & 810 & 1080 \\
\hline \multirow{6}{*}{ Logarithmic } & $\mathrm{k}_{1}$ & 0.014 & 0.012 & 0.016 & 0.26 & 0.308 & 0.388 & 0.279 & 0.363 & 0.328 & 0.185 & 0.215 & 0.293 \\
\hline & a & 0.712 & 0.785 & 0.782 & 1.03 & 1.033 & 1.018 & 0.987 & 0.988 & 1.097 & 1.13 & 1.1 & 1.1 \\
\hline & $\mathrm{b}$ & 0.293 & 0.216 & 0.222 & -0.019 & -0.026 & -0.004 & 0.018 & 0.023 & -0.09 & -0.12 & -0.094 & -0.11 \\
\hline & RMSE & 0.00493 & 0.0112 & 0.0109 & 0.0159 & 0.0106 & 0.0204 & 0.0047 & 0.0116 & 0.0118 & 0.0122 & 0.0181 & 0.0097 \\
\hline & $\mathrm{P} \%$ & 0.84 & 1.85 & 2.28 & 7.88 & 5.57 & 10.8 & 1.65 & 3.49 & 5.01 & 5.9 & 6.87 & 2.64 \\
\hline & $\mathrm{R}^{2}$ & 1 & 0.997 & 0.998 & 0.997 & 0.999 & 0.996 & 1 & 0.998 & 0.998 & 0.998 & 0.997 & 0.991 \\
\hline \multirow{7}{*}{ Two term } & $\mathrm{k}_{0}$ & 0.013 & 0.009 & 0.011 & 0.272 & 0.328 & -0.392 & -0.329 & 0.35 & 0.395 & 0.236 & 0.339 & 0.365 \\
\hline & $a$ & 0.755 & 0.985 & 0.992 & 0.507 & 0.488 & 0.571 & 0.001 & 1.01 & 0.51 & 0.508 & 0.264 & 0.667 \\
\hline & $\mathrm{k}_{1}$ & 0.248 & 0.011 & 0.008 & 0.509 & 0.525 & 0.504 & 1.003 & 0.001 & 0.51 & 0.524 & 0.759 & 0.339 \\
\hline & $\mathrm{b}$ & 0 & -0.013 & -0.018 & 0.272 & 0.328 & 0.392 & 0.272 & 0.48 & 0.395 & 0.236 & 0.339 & 0.365 \\
\hline & RMSE & 0.00433 & .0105 & .00297 & 0.0167 & 0.0119 & 0.0204 & 0.0044 & 0.0111 & 0.0191 & 0.0250 & 0.0351 & 0.0187 \\
\hline & $\mathrm{P} \%$ & 0.74 & 1.71 & 0.6 & 7.07 & 5.62 & 10.37 & 1.88 & 4.69 & 7.76 & 11.14 & 12.55 & 0.95 \\
\hline & $\mathrm{R}^{2}$ & 1 & 0.998 & 1 & 0.997 & 0.999 & 0.996 & 1 & 0.999 & 0.995 & 0.993 & 0.992 & 0.995 \\
\hline
\end{tabular}

association with osmo-air drying was in agreement with results reported for carrots (Prabhanjan et al., 1995), sultanas (Karathanos and Belessiotis, 1997) and banana (Maskan, 2000, 2001).

\section{Modeling of drying curves}

Drying data was used to test applicability of these models and models parameters along with $R^{2}$, RMSE and P\% were evaluated (Table 1). As the whole data of combine drying did not fit adequately, therefore model fitting was accomplished on air drying and microwave finish drying section separately. The results showed that both the models gave adequate fit for combine dried samples. The obtained values of model parameters $\left(k_{2}\right.$ and $\left.b\right)$ for two term model showed decreasing trend with air temperature for air dried samples whereas two term model parameters $\left(k_{1}\right.$ and a) and logarithmic model parameters $\left(k_{1}, a\right.$ and b) was not shown any clear trend with air temperature. On the other hand, for microwave finish dried sample, no clear trend was obtained for all models parameters including logarithmic and two term models. The maximum mean value of $R^{2}$ and minimum mean values of RMSE and $\mathrm{P} \%$ evaluated for air dried $(0.999,0.0103$ and $1.92)$ and microwave finish dried sample $(0.998$, 0.0123 and 5.43) at the two term and logarithmic model, respectively indicated a good fit of models to experimental data.

\section{Quality attributes}

\section{Rehydration capacity}

During rehydration, the percentage increase in original weight of dried sample mainly depends upon the porosity of sample. The rehydration characteristics are used as quality index of dried product. Further, it also indicates the physicochemical changes occurred in sample as influenced by processing conditions, pretreatment and composition of biological materials. The rehydration capacities of dried beetroot for different treated combinations were calculated by Equation 6 and presented graphically in Figure 3a. From an examination of figure it was observed that rehydration ratio gradually decreased with increase in air temperature whereas with microwave power, it resulted in to decrease in rehydration capacity. This might be due to change in texture or structure of sample during drying. The microwave energy is quickly absorbed by water molecules present in sample and created flux for faster evacuation of moisture thereby preventing shrinkage and case hardening and 


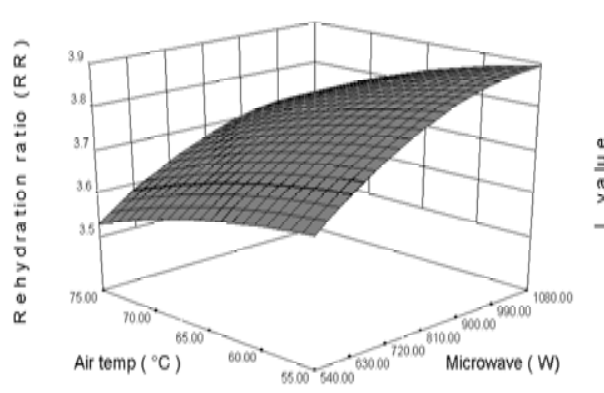

(a)

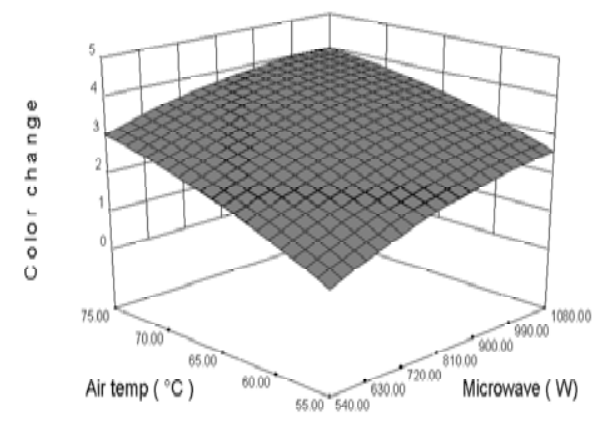

(e)

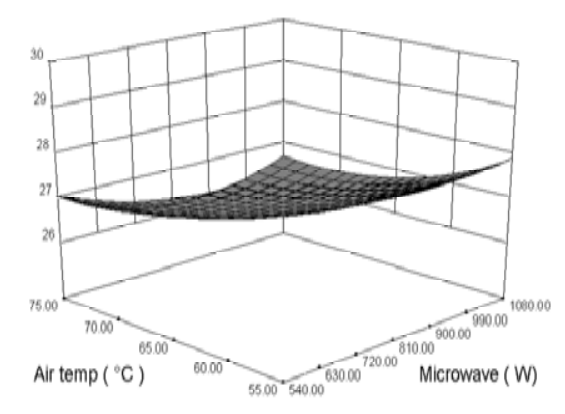

(b)

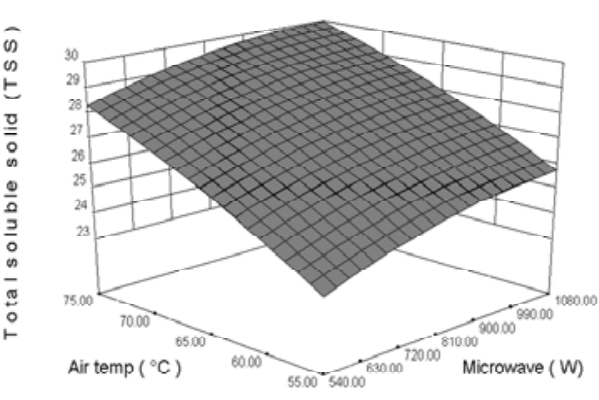

(f)

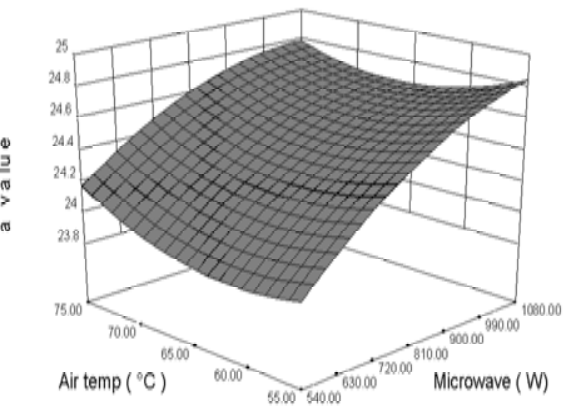

(c)

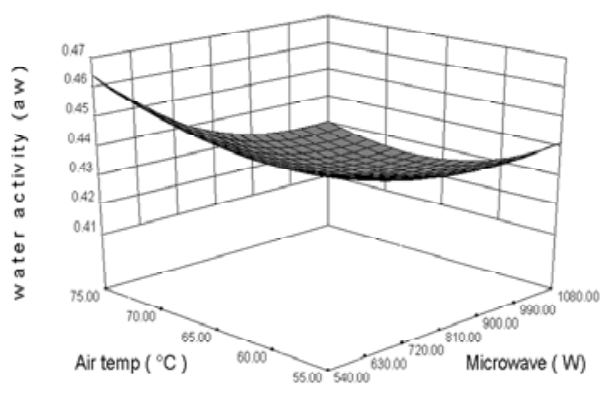

(g)

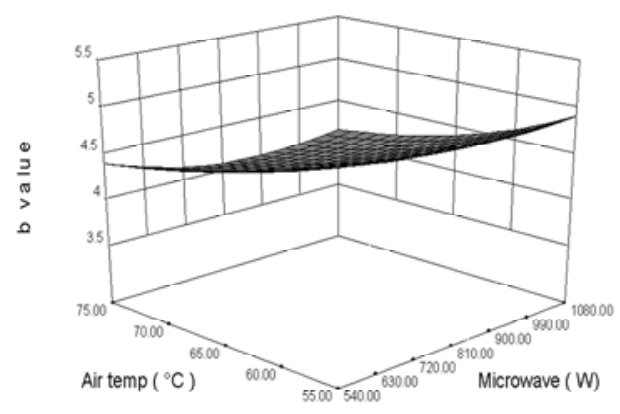

(d)

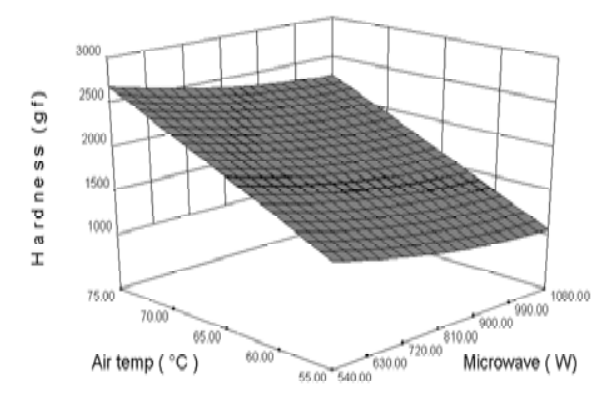

(h)

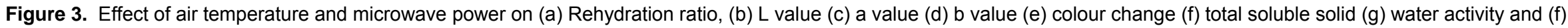
hardness hot air microwave finis drying of osmotically pretreated beetroot slices.

improved rehydration properties of sample. The maximum value for RR (3.9) was observed at lowest air temperature of $55^{\circ} \mathrm{C}$ and highest microwave power level of $1080 \mathrm{~W}$, suggesting better retention of water during rehydration. Although, regained moisture content of dehydrated product during rehydration was not equivalent to initial moisture content, but it was proximate to initial moisture content of fresh sample. Similar results have been observed by Maskan (2000, 2001) for banana and kiwifruit respectively.

\section{Color}

The effect of air temperature and microwave power level (MW) on color of beetroot were evaluated and presented in Figure $3 b$ to $d$. A sample with color values closest to original value of fresh sample is preferred. The tristimulus value of $L$, $a$ and $b$ of fresh beetroot were 29.55, 22.95 and 5.4 respectively. The microwave drying in association with hot air drying resulted into increase value of ' $a$ ' with increase in food temperature that is, higher the air temperature and microwave power level, the higher the redness of 
beetroot (Figure 3c). However, the $L$ and $b$ values were found to decrease gradually with increase in air temperature and microwave power level (Figure $3 \mathrm{~b}$ and d). This can be explained by the degradation of carotenoids and flavonoids, pigments responsible for the red color and also by maillard and the non-enzymatic browning reactions occurred at higher air temperature and microwave power. The maximum value of ' $L$ ' and ' $b$ ' and lowest value of ' $a$ ' was obtained at lowest air temperature of $55^{\circ} \mathrm{C}$ and lowest $\mathrm{MW}$ of $540 \mathrm{~W}$, suggesting better retention of pigments responsible for color of dehydrated beetroot at low air temperature and MW. The color change values, which take into account changes in lightness, redness and yellowness, were also compared. From Figure $3 e$, it was observed that microwave drying at lowest power in combination with air drying at lowest temperature resulted in to lesser color change compared to other treatment combinations. The lower color degradation of microwave finished dried beetroot may be due to substantial reduction in maillard reaction occurred at high air temperature and microwave power level. The minimum value of color change $(\Delta \mathrm{E})$ was observed at, air temperature of $55^{\circ} \mathrm{C}$ and $\mathrm{MW}$ of 540 W.

\section{Total soluble solids}

The effect of air temperature on total soluble solid (TSS) of dried beetroot for different levels of microwave power has been presented in Figure $3 \mathrm{f}$. From figure it was observed that microwave drying at higher power in combination with air drying at highest temperature resulted in to maximum total soluble solid compared to other treatment combinations. In general, TSS content of osmotically pretreated sample is higher as solid diffuses into intercellular spaces and along the cell wall due to generation of concentration gradient. When osmotically treated sample further dried by air-microwave drying, moisture inside the cell membrane started diffusing outward from surface to ambient and leaving behind the solid content. With passage of drying time, most of free water evaporated and solid remained choked into the pores of food and hence enhanced the total soluble solid content of food. The highest value of TSS during microwave finished drying of beetroot may, therefore be due to quick evaporation of water molecules occurred at both high air temperature and microwave power level. The maximum value of 'TSS (24.8) was observed at highest air temperature of $75^{\circ} \mathrm{C}$ and highest microwave power level of $1080 \mathrm{~W}$ whereas, the minimum value of TSS (23.9) was observed at air temperature of $55^{\circ} \mathrm{C}$ and MW of $540 \mathrm{~W}$.

\section{Water activity}

The reduction in moisture level reduced the water activity of dehydrated sample. A relatively low value of water activity of dehydrated sample that is, less than 0.6 is the recommended level for safe and long term storage. Lower value of water activity prohibts the microbial activity and thereby prevents the oxidative and enzymatic degradation of sample. The effect of air temperature and microwave power level on water activity $\left(\mathrm{a}_{\mathrm{w}}\right)$ of dehydrated beetroot has been shown in Figure $3 \mathrm{~g}$. From the figure, it can be observed that all the values generally range from 0.42 to 0.465 for $25^{\circ} \mathrm{C}$ which implied dried beetroot is unsusceptible to physicochemical or microbiological deterioration. Further, it showed that water activity decreased with increase in microwave power level and air temperature. This was related to the water loss during drying process. At higher temperatures and power level, the water evaporation rate was higher, influencing the moisture content and consequently water activity in the product. The maximum value of $\mathrm{a}_{w}(0.464)$ was observed at, air temperature of $55^{\circ} \mathrm{C}$ and $\mathrm{MW}$ of 540 W.

\section{Hardness}

Textural properties of dehydrated products are normally measured as puncture force, which is a measure of the hardness of the product surface and is an indicator of the extent of case hardening that has occurred during drying (Lin et al., 1998). The effect of air temperature and microwave power level on hardness ( $g-f)$ of dehydrated beetroot has been depicted in Figure $3 \mathrm{~h}$. The increase in hardness with increase in air temperature was observed due to the porous structure of dehydrated sample that led to quick transport rate of water molecules. On the contrary, decrease in hardness with increase in microwave power level was associated due to puffing phenomenon of biological material being dehydrated. This puffed structure of microwave finished dried sample was more susceptible to local cracking and yielded under compressive load than the shrunk structure as obtained at highest air temperature and lower microwave power level. The results obtained were in agreement with those reported by Xiao et al. (2009), Funebo et al. (2002) and Abano et al. (2011) for dehydrated sweet potato, apple and garlic slices respectively. The maximum value of hardness (2667.085 gf) was observed at, air temperature of $75^{\circ} \mathrm{C}$ and $\mathrm{MW}$ of $540 \mathrm{~W}$.

\section{Conclusion}

From the above results it can be concluded that osmotic dehydration was an effective pretreatment prior to combine drying as it reduced the final drying time and improved the quality of dried sample. Further, raising hot air drying temperature followed by high microwave power also played a great contribution in raising drying rate and shortening total drying time. A good agreement between 
experimental and predicted data was found for two term and logarithmic models for hot air dried and microwave finish dried sample, respectively. Microwave in association with hot air drying of osmotically pretreated beetroot slices exhibited better rehydration properties, lesser color degradation, stiff texture, maximum total soluble solid and safe water activity level as compared to fresh sample of beetroot. Finally, it can be concluded that the osmotic dehydration in combination with hot air followed by microwave finish drying can be used for preservation of beetroot slices with retention of high quality.

\section{Conflict of Interests}

The author(s) have not declared any conflict of interests.

\section{ACKNOWLEDGEMENT}

The authors would like to thank the faculty of department of Processing and Food Engineering, Punjab Agricultural University, India for their assistance in the research.

\section{REFERENCES}

Abano EE, Ma H, Qui W (2011). Effects of pretreatments on the drying characteristics and chemical composition of garlic slices in a convective hot air dryer. J. Agric. Food. Tech. 1(5):50-58.

Andres A, Bilbao C, Fito P (2004). Drying kinetics of apple cylinders under combined hot air -microwave dehydration. J. Food. Eng. 63:7178.http://dx.doi.org/10.1016/S0260-8774(03)00284-X

AOAC (2000). Official method of analysis. Association of official analytical chemists. Washington DC, USA.

Ceylan I, Aktas M, Dog an H (2007). Mathematical modeling of drying characteristics of tropical fruits. Appl. Thermal. Eng. 27:19311936.http://dx.doi.org/10.1016/j.applthermaleng.2006.12.020

Clary CD, Wang SJ, Petrucci VE (2005). Fixed and incremental levels of microwave power application on drying grapes under vacuum. J. Food. Sci. 70(5):344-349.http://dx.doi.org/10.1111/j.13652621.2005.tb09975.x

Cui ZW, Xu SY, Sun DW (2005). Temperature changes during microwave-vacuum drying of sliced carrots. Drying Technol. 23:10571074.http://dx.doi.org/10.1081/DRT-200059136

Figiel A (2010). Drying kinetics and quality of beetroots dehydrated by combination of convective and vacuum-microwave methods. J. Food. Eng. 98:461-470.http://dx.doi.org/10.1016/j.jfoodeng.2010.01.029

Funebo T, Ohlsson T (1998). Microwave-assisted air dehydration of apple and mushroom. J. Food. Eng. 38:353367.http://dx.doi.org/10.1016/S0260-8774(98)00131-9

Funebo T, Ahrne L, Prothon F, Kidman S, Langton M, Skjoldebrand C (2002). Microwave and convective dehydration of ethanol treated and frozen apple-physical properties and drying kinetics. Int. J. Food. Sci. Technol.37(6):603-614.http://dx.doi.org/10.1046/j.1365-

2621.2002.00592.x

Jia LW, Islam MR, Mujumdar AS (2003). A simulation study on convection and microwave drying of different food products. Drying Technol. 21(8):1549-1574.http://dx.doi.org/10.1081/DRT-120024679

Karathanos VT, Belessiotis VG (1997). Sun and artificial air drying kinetics of some agricultural products. J. Food. Eng. 31:3546.http://dx.doi.org/10.1016/S0260-8774(96)00050-7
Kostaropoulos AE, Saravacos GD (1995). Microwave pretreatment for sun-dehydrated raisins. J. Food. Sci. 60:344347.http://dx.doi.org/10.1111/j.1365-2621.1995.tb05669.x

Kumar V, Kumar G, Sharma PD (2009). Effect of Osmo-convective drying on quality of litchi. J. Agric. Eng. 46(4):31-35.

Lin TM, Durance TD, Scaman CH (1998). Characterization of vacuum microwave, air and freeze dried carrot slices. Fd. Res. Int. 31(2):111117.http://dx.doi.org/10.1016/S0963-9969(98)00070-2

Madamba PS (2003). Thin layer drying models for osmotically pre-dried young coconut. Drying Technol. 21:17591780.http://dx.doi.org/10.1081/DRT-120025507

Maskan M (2000). Microwave/air and microwave finish drying of banana. J. Food. Eng. 44:71-78.http://dx.doi.org/10.1016/S02608774(99)00167-3

Maskan M (2001). Drying, shrinkage and rehydration characteristics of kiwifruits during hot air and microwave drying. J. Food. Eng. 48:177182.http://dx.doi.org/10.1016/S0260-8774(00)00154-0 http://dx.doi.org/10.1016/S0260-8774(00)00155-2

Ponting JD (1973). Osmotic dehydration of fruits - recent modify. Cations and applications. Proc. Biochem. 8:18-20.

Prabhanjan DG, Ramaswamy HS, Raghavan GSV (1995). Microwaveassisted convective air drying of thin layer carrots. J. Food. Eng. 25:283-293.http://dx.doi.org/10.1016/0260-8774(94)00031-4

Prothon F, Ahrne LM, Funebo T, Kidman S, Langton M, Sjoholm I (2001). Effects of combined osmotic and microwave dehydration of apple on texture, microstructure and rehydration characteristics. LWT-Food Sci. Technol. 34:95-101.

Ranganna S (2000). Handbook of Analysis and Quality Control for Fruits and Vegetable Products. Tata McGraw Hill Publishing Co. Ltd., New Delhi.PMid:10821433

Ruiz Diaz G, Martı'nez-Monzo' J, Fito P, Chiralt A (2003). Modelling of dehydrationerehydration of orange slices in combined microwave/air drying. Innovative Food Sci. Emerg. Technol. 4(2):203209.http://dx.doi.org/10.1016/S1466-8564(03)00016-X

Sacilik K, Keskin R, Elicin AK (2006). Mathematical modelling of solar tunnel drying of thin layer organic tomato. J. Food. Eng. 73:231238.http://dx.doi.org/10.1016/j.jfoodeng.2005.01.025 http://dx.doi.org/10.1016/j.jfoodeng.2005.03.024

Xiao HW, Lin H, Yao XD, Du ZL, Lou Z, Gao J (2009). Effects of different pretreatment on drying Kineticsand Quality of sweet potatoes bar undergoing air impingement drying. Int. J. Food. Eng. 5(5):5.http://dx.doi.org/10.2202/1556-3758.1758

Zhang M, Tang J, Mujumdar AS, Wang S (2006). Trends in microwave related drying of fruits and vegetables. Trends Food Sci. Technol. 17:524-534.http://dx.doi.org/10.1016/j.tifs.2006.04.011 